\title{
World Finance: A Textbook Presentation and Overview
}

\author{
Mikhail Zharikov
}

\begin{abstract}
Financial globalisation is a general trend of contemporary world economic development that multinational corporations largely drive. Many of them come from English-speaking countries. Many of them are of the U.S. origin, which is why globalisation is often misunderstood and misinterpreted as Americanisation. English is the leading language of globalisation. Even European leaders of supranational level have to speak, communicate and pass E.U. legislation in English. That is why teaching and studying world finance in English is given a high priority in many countries. Russia is no exception to the rule and the Financial University under the Government of the Russian Federation (the University of Finance). This book attempts to outlay the theoretical and practical foundation for the world finance. It contains basic world finance terminology. The textbook can be recommended for teaching world finance and related subjects.
\end{abstract}

Keywords: world finance; discount rate; financial globalisation

JEL Classification: F37

(c) Mikhail Zharikov, 2021

\section{Introduction}

2020 was both good and bad. It was bad because of isolation, disease, social distancing and death. It was good for writing and publishing books, though. 2020 saw a record number of publications in science and technology in recent decades. There were also several textbooks published. One of the professional textbooks that went in the press under the umbrella of the Financial University under the Government of the Russian Federation is World Finance. The textbook's author is Dr Mikhail V. Zharikov, Professor at the University's World Finance Department. The textbook (pictured) appeared in KNORUS Publishing House (World finance / Жариков М.B. / Publishing House: OOO "KnoRus" (Moscow). 354 p. ISBN: 978-5-406-07635-4). The expert board recommends studying economics and finance at bachelor programs in higher schools.

A group of professionals reviewed the textbook and included Zbigniew Mierzwa, Doctor of Economics, retired adjunct of the University of Warsaw, the editor at the Review of Business and Economics Studies; Yelizaveta S. Sokolova, Doctor of Economics, Professor at the Financial University under the Government of the Russian
Federation; Vladimir N. Kostornichenko, Doctor of Economics, Professor at the Moscow State Linguistic University; Vyacheslav V. Karlusov, Doctor of Economics, Professor at the Moscow State Institute (University) of International Relations under the Foreign Affairs Ministry of the Russian Federation.

\section{Textbook Structure}

The underlying textbook consists of eleven chapters describing the current issues in world finance. Chapter 1 "Introduction to international finance: basic terminology" looks into the significance of international finance, types of assets in the international financial markets, the value of the financial assets as well as financial markets dynamics, basic characteristics and market participants (The textbook, pp. 12-23). This course's objective is to convince the reader that they do not have to be super smart or super lucky to be a successful investor. Investing well is not about using fancy models or being full hardy; like many things in life, it is about mastering the fundamentals. Here is an example about one of the most brilliant investment decisions that the international financial markets know so far. 


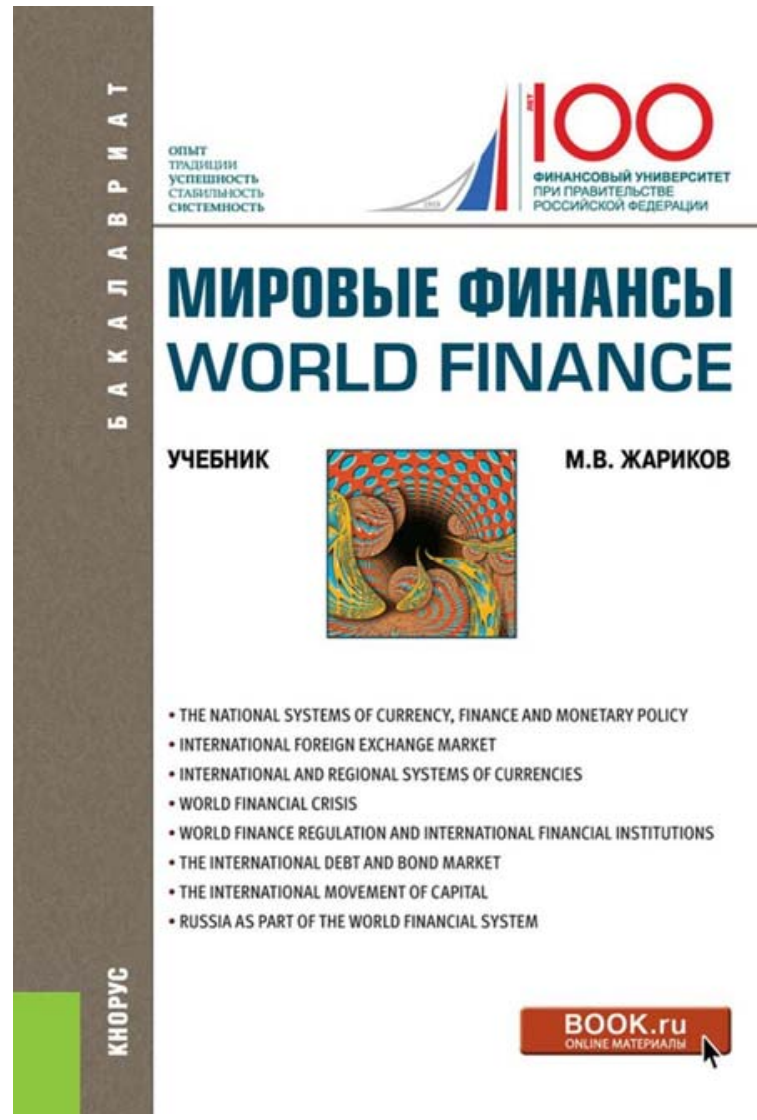

First of all, the book is going to start making the case that the basic ideas behind investing are sensible and easy to understand. Then the book is going to talk about the risks of investing. It will tell the reader the most serious threats to the investments and explain why they are so bad. But the book also demonstrates that there are sensible and effective ways to protect investments from these risks. By the end of this chapter, the reader will have a better picture of what they are getting themselves into when they invest - the good things as well as the bad. And hopefully, any sense of frustration or dread that the reader associates with investing will start to fade and may even be replaced by a little excitement. There is hope all this talk about risk makes someone feel better about investing because it should (Boddin, Stähler, 2018).

Understanding the main risks to invest in is the first step toward managing them. And one has learned that there are simple and effective ways to manage these risks. This chapter has also provided an opportunity to learn some of the fundamental ideas of investing. During the rest of this textbook, one will build on this foundation by learning about different available $\begin{array}{lllllllllll}\text { Б } & \text { А } & К & \text { А } & \text { Л } & \text { А } & \text { В } & \text { Р } & \text { И } & \text { А } & \text { Т }\end{array}$

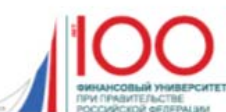

М.В. Жариков

МИРОВЫЕ ФИНАНСЫ WORLD FINANCE

Рекомендовано

Экспертиым советом умО в системе ВО и спо

8 качестве учебниха

направлений бакалавриата

Финансы: и ะ экономикар

\section{BoOK.ru \\ КНОРУC - МОСКВА 2020}

investments and how to choose the ones that are best for the investor (Beetsma, Giuliodori, De Jong, Widijanto, 2016). The reader will also learn about different investing strategies so that he/she can act to protect themselves from risks and also take good advantage of good opportunities. And they will learn some financial planning tools. They can help one reach financial goals. If the readers take their time to learn the fundamentals of investing and make their own investment plan, then they will feel prepared to make investment decisions and manage their investments. So, they can stop worrying now and start investing.

Chapter 2 "The national systems of currency, finance and monetary policy" is about the Federal Reserve of the United States and the U.S. national system of currency, the Gold Standard as a central bank for a country, the Federal Reserve System during the Great Depression, the Federal Reserve after the Bretton Woods the Federal Reserve anti-inflation policy, the Great Moderation in the U.S. monetary policy as well as the housing bubble as a prelude to world financial crisis of 2008 (The textbook, pp. 24-69). This chapter provides an extraordinary opportunity for the students to 
gain insight into the U.S. central banking system in a wide range of issues that affect this country and the world.

The chapter is going to talk about the Federal Reserve and the Financial Crisis specifically. When one talks about the issues that just occurred in the last few years, it makes the most sense to think about it in a broader context of central banking as has taken place over the centuries. So, even though the chapter will be focusing a good bit of the contents quickly on the financial crisis and how the Fed responded to it, one needs to go back and look at the broader context (Cohen, 2012).

Hence as the book will talk about the Fed, it will also be talking about the origin and mission of central banks in general. And it is going to look at previous financial crises, most notably the Great Depression and see how that informed the Fed's actions and decisions in the recent crisis.

The chapter then discusses what central banks are, what they do, how central banking got started in the United States, and some history. It will talk about how the Fed engaged with its first great challenge - the Great Depression of the 1930s.

The next chapters will take up the history. They will review developments in central banking and with the Federal Reserve after World War II, talking about the conquest of inflation, the Great Moderation and other developments that occurred after World War Two. But it will also spend a good bit of time talking about the build-up to the crisis and some of the factors that led to the crisis of 2008-2009.

The next chapter will get into the more recent events. It will talk about the intense phase of the financial crisis with causes and implications and particularly the response to the crisis by the Federal Reserve and by other policymakers. And then, finally, the book will look at the aftermath. It will talk about the recession that followed the crisis, the policy response of the Fed, including monetary policy, the broader response in terms of changes in financial regulation, and a little bit of a forwardlooking discussion about how this experience will change, how central banks operated, and how the Federal Reserve will operate going forward (De Haas, Horen, 2011).
Chapter 3 "International foreign exchange market," tells about the phenomenon of foreign assets and the basics of foreign exchange trading (The textbook, pp. 70-81). In this chapter, the author is going to branch out into the assets that investors may also want to consider. Some of the assets the reader will learn about in this chapter are ones that can be considered must-haves for an investor's portfolio. Others are optional, and there will even be tossed in a few assets that the reader hears about a lot, but sometimes it is best off if the reader avoids them (Johnson, 2013).

In this chapter, there are actually included both must-have investment and one to avoid. And they are both different types of foreign assets. It is time that the textbook got into some more details about what they can do for investors.

The chances are that if someone is holding well-diversified mutual funds, or if a pension covers someone, they already have some foreign assets in their portfolio. After all, there are plenty of global blue-chip firms that are not headquartered in the U.S., like Toyota or Adidas or Petrobras. And bonds from foreign companies or foreign governments can also offer safe and attractive returns. But most of the investors, when it comes right down to it, would rather invest in companies that are closer to home (Kadayan, 2014).

As promised, the chapter will turn to the foreign asset that one should probably avoid investing in - foreign exchange. Foreign exchange, also known as foreign currency trading, or simply forex trading, can seem really attractive. It is one of the largest and most active asset markets on the planet. Each day about five trillion dollars in currencies get traded, i.e. two and a half-trillion dollars of various currencies are traded for two and a half-trillion dollars of other various currencies. And the rates always seem to be moving up and down. It seems like there are plenty of opportunities for traders to make money. And some of the most legendary trades involve large bets on the direction of exchange rates (Dorrucci, McKay, 2011).

It is easy to lose money if exchange rates change. And they tend to bounce around quite a bit. Judging by the surge in ads in the past few years, it seems like there has been an explo- 
sion in interest in the carry trade among retail investors. And even some newcomers used to dream about being able to do this trade in the abstract.

But again, this strategy boils down to buying currency and using a lot of leverage. It is just as easy to lose a lot of money as it is to make it.

The upshot of it, of course, do not to try this at home.

In the end, remember the idea of investing in real assets. There are plenty of amazing opportunities outside the U.S. - about 80 trillion dollars' worth, according to the statistics one saw earlier. And they are all rooted in real assets.

Do invest abroad but do not invest in money.

Invest in the companies and projects that make money, no matter what colour the money is or what kind of funny picture they put on it.

Do not overweight foreign markets since many of them have a lot of growing up to do, but do make enough room in the portfolio that one can benefit from their growth and development as well as from the diversification protection that they offer.

Chapter 4 "International and regional systems of currencies", is a useful guide on the development of the international system of currencies, the history and the major features of the regional system of currency, the U.S. dollar as a world currency and the prospects of the U.S. dollar in the international monetary system (The textbook, pp. 82-111). Winston Churchill once said that 'the further you look into the past, the further that you can see into the future.'

This chapter is all about creating one's own crystal ball, being able to gaze into the future, being able to change this crisis, the greatest crisis in the history of humankind, into one's great opportunity.

Studying the financial markets leads all the way to studying the economy. And when one starts reading about the global economy, the people concerned with trade deficits and budget deficits are the hard money advocates and the gold community they encounter. And once someone starts reading them, they also write about monetary history, and then the reader realises that monetary history just repeats and repeats over and over again, echoing all the way back to the beginning of civilisation (Gourinchas, Obstfeld, 2012).

It is one of the most predictable hidden secrets of money, which some economists call the seven stages of empire. It is a long-term cycle that echoes throughout history right to this very day and is basically a societal pendulum that swings from quality money to quality currency and back again to quality money. It always plays out in seven stages. It always ends with gold delivering a knock-out blow to debased currencies, and it goes like this:

Stage One: A country starts with good money that is either gold or silver or backed by gold or silver.

Stage Two: As it develops economically and socially, it begins to take on more and more economic burdens adding layer upon layer of public works.

Stage Three: As its economic affluence grows, so does its political influence, and it increases expenditures to fund a massive military.

Stage Four: Eventually, it puts its military to use, and expenditures explode.

Stage Five: To fund a war, it steals the wealth of its people by debasing their coinage with base metals or by replacing their money with the currency that can be created in unlimited quantities.

Stage Six: The loss in purchasing power of the expanded currency supply is sensed by the population and the financial markets, triggering a loss of faith in the currency.

Stage Seven: A mass movement out of currency into precious metals and other tangible assets takes place. The currency collapses, and gold and silver rise in price as they account for the huge amount of currency created.

This process transfers massive wealth to those who had the foresight to position themselves beforehand in real money - gold and silver (Lane, Milesi-Ferretti, 2011).

A very interesting phenomenon which comes out here is that every $30-40$ years there is a different monetary system, sometimes 30 years, the other times 28 years, 39 years plus, which means that probably the world is going to have a new monetary system in this decade or the next one. The world is going to experience a huge deflationary crash. The world will probably end up with a new monetary system, probably 
after governments try and print their way out of this and cause hyperinflation of all the currencies. And people will just lose confidence in the currency. And what do they always go back to, throughout history, time after time, for the last 5,000 years? Actually, they always went back to gold and silver (Khan, Zhao, Zhang, Yang, Haroon, Jahanger, 2020).

In a world of floating currencies - which is what all national currencies are today - they move up and down relative to each other, but they are all sinking relative to gold. That includes dollars as well as the euro and the British pound, and all the others. They are going to continue to lose value and continue to lose purchasing power (Milesi-Ferretti, Tille, 2011).

Some economists think there is no way of avoiding what is coming. There is no way to fix it right now. There is only a way to either let someone drop out or to benefit from it. And what is needed to do right at the moment is to make sure that it is not just a few of the big investors in the world that are going to end up with all the profits. It is quite necessary to make sure that there are as many small investors as possible that are benefitting from it, because that is what makes society run, i.e. the middle class and a small investor (Obstfeld, 2011).

From the previous chapters, it became clear that the dollar-gold standard was put in place by a series of accidental events that were very fortunate for the United States because it gave it an advantage over the rest of the world. But the politicians over the past decade or so have abused this privilege as though it was their birthright. And the rest of the world are turning their backs on the U.S. dollar standard. It is going to cause a financial calamity the likes of which the world has never seen before. And it is going to be devastating for most people. Some of the damage has already been done. So, this chapter is going around trying to alert people and show them how they can protect themselves and turn this into a great opportunity for themselves.

There is always one result from what the countries of the world are doing right now expanding the currency supplies all over the planet - that is higher gold and silver prices. The world has got to get back to free markets, free people and sound money. U.S. history proves that this is the road to maximum prosperity (Ostry, 2012).

The chapter provided several astronomical prices for gold someday in the future. But it is not the question about the price measured in dollars; it is the question of how much its value is, what it is worth, and how much stuff it can purchase. The price measured in dollars or any currency, for that matter, is just a combination of numbers. And it really does not mean anything. Some numbers are created by the world's central banks, by the commercial banks' system, and people are forced to transact in these currencies (Patil, Kulkarni, 2011).

The next chapter is going to clear away the veil off national currencies and show how the world monetary system really works and how all national currencies will continue losing value. They can't maintain purchasing power over any reasonable period of time.

As for the golden nails in the dollar's coffin, there is already much more of them. But the truth is that like many times before, there are brief moments in history where the safest asset class or the safe-haven investment for the last 5,000 years also becomes the asset class that has the greatest potential gain in purchasing power.

The previous chapter was dealing much with the swap lines to bypass the U.S. dollar. The East - West cycle, the maximum spending demographic, the wealth distribution cycle, the household debt-to-income-ratio cycle, the stock market cycles, the Kondratiev wave, and the world monetary systems are all pointing to a massive deflation that should be coming in the future. In Japan, they are trying to beat deflation by just expanding the currency supply, and it does not work. Some Keynesians think it will work. But Japan has been trying it now for two decades. And it has not worked yet. And so, now the U.S. is trying (Reinhart, Rogoff, 2011).

It is starting to fall apart. And it is falling apart at an increasing rate. It is happening faster and faster. This chapter will try to explain why there is deflation coming. And it is coming soon.

The U.S. dollar standard as the world reserve currency is going to be abandoned someday. Its days are numbered. The previous chapters 
elaborated on the death of the dollar standard. And the world is getting closer and closer to that day. And it seems like every week now, there is another nail in the dollar's coffin. This is just an update on that and the progression of it (Rousseau, Wachtel, 2011).

The previous chapters also dealt with how the world monetary system has had evolved, and they showed that every thirty to forty years, the world has a brand-new monetary system. And people did not know that they are going to go through that and that they will go along with pressures build up in the monetary system. It starts to develop stress cracks and implode. There have been emergency meetings of a bunch of financial ministers during the G20 summits. And they are trying to come up with a new world monetary system.

Chapter 5 "The World financial crisis", is talking about the years of the Great Crash, the Financial Crisis of 2008-2010, the Federal Reserve's response to the financial crisis, major bankruptcies in the U.S. financial system, money-market funds in the U.S. financial system, the Federal Reserve's bailout programmes as well as the Great Euro Crisis (The textbook, pp. 112-181). After having studied the origins of the financial crises in the 1930s, this chapter is devoted specifically to financial globalisation and financial crises in the early 21 st century. It is obviously a topic that everyone is interested in after the global financial crisis of 2008-2010, the worst global financial crisis since the Great Depression. Its effects are still felt across the world. Both industrial and emerging countries still suffer from high unemployment. In some of them, GDP has not yet reached pre-crisis levels. And this global crisis - if it were not enough was followed very quickly by the Eurozone's sovereign debt crisis, which despite the fact that Ireland and now just recently Portugal have returned to private borrowing markets, is not resolved at all and is pretty much in remission but could come back.

The global crisis is absolutely huge in its effects. It is very obvious, and then the euro crisis, which like many crises can be seen most clearly with its effects in the euro area, but arguably their spill-overs to developing world as well became greater over this period as countries became more highly linked not only by trade but importantly in view of financial markets (Kasekende, Brixova, Ndikumana, 2010).

In fact, the above events are all different sorts of crises with very different effects. A lot of banking distress marked the recent crisis. And so, banking crises are one prominent form of crisis. Banks have short-term liabilities but tend to hold longer-term assets or more illiquid assets. They provide liquidity to depositors and other short-term creditors. But if all of those depositors or creditors demand repayments at once, the bank is going to have a lot of trouble meeting those obligations. When this happens on a large scale, banking crises arise.

Governments sometimes default on their debt obligations. Most recently, one saw a very well publicised technical default by Greece in the Eurozone. Still, other countries default all the time, particularly in the developing and emerging world, and, of course, even in the U.S.

Chapter 6 "World finance regulation and International Financial Institutions", is committed to the role of the United Nations Organisation in Reforming the Global Financial Architecture, the regulatory framework of international finance after the global financial crisis of 2008-2010 and regulating consumer financial products: Evidence from credit cards (The textbook, pp. 182-239). This chapter presents the leading thoughts and views in contemporary economic science on how to move to a more stable economic and financial architecture. This chapter contributes to macroeconomic and monetary theory to the development of economic and trade theory. It helps to explain the circumstances in which markets do not work well and how the elected government interventions can improve their performance. This chapter also examines international monetary and financial system reforms required to respond to the recent global crisis. The recent crisis has been clearly the worst crisis since the Great Depression. And the response to the crisis has been very distinctive and unique. At the very beginning, it was quite clear that the kind of global architecture that the world had before the crisis in terms of responding to global problems was inadequate. The major form of the discussion was the G7. And the good news was that the G7 recognised that it was not up to the task. 
When one sees a very big stimulus package, one should not be misled. It's being offset by what is happening at the state and local level. But the real problem is 2020. When the federal stimulus ended, there was a need for a second stimulus, but because of the way that the money was misspent on the bank bailout, it is going to be very difficult to get a second round of stimulus (Salisu, Akanni, 2020).

So, all of that says that the potential for a robust recovery within the United States is a bit limited. But part of the problem is that the government has not done anything about the two underlying problems, i.e. the growing inequality that was mentioned within most countries of the world or the problem of the reserves, the growth of global reserves (Tripathi, Kaur, 2020).

Obviously, based on the crisis and what happened and the effects that the world is still feeling, it is now clear that maintaining financial stability is just as an important responsibility as monetary and economic stability. Indeed, this is very much a return to where the Fed came from in the beginning. Remember, the reason the Fed was created was trying to reduce the incidence of financial panics. So, financial stability was the original goal of creating the Fed (Vayanos, Woolley, 2013).

The U.S. has come full circle. But financial crises will always be with the countries of the world. That is probably unavoidable. There have been financial crises for 600 years in the Western world. Periodically, there are going to be bubbles or other instabilities in the financial system. But given what the potential for damage is now, as one has seen, it is really important for central banks and other regulators to do all that they can (Yu, 2014).

The regulators should try to anticipate or prevent a crisis, but if a crisis happens, to mitigate it and make sure the system is strong enough, it will be able to make it through the crisis intact.

Chapter 7 "The International securities market" looks into the international aspects of trading in stocks, equities and related assets and the fundamentals-Based Analysis of International Market of Stocks (The textbook, pp. 240-260). This chapter is going to start to take an in-depth look at different types of invest- ments. Although there are literally thousands of different financial products for people to invest in, most are made up of the same basic few types of financial instruments.

So, one can consider this chapter the introduction to the main building blocks of investments. Later in the course, there will also be an introduction to a few more building blocks that one might want to add to the set. But the wants that are shown here are what can be considered essentials. And the investment the chapter wants to start with are stocks.

At this point, the chapter has covered just about everything one needs to know about stock investing except which stocks to pick.

The chapter allowed to learn some key facts about how actually stocks work, and some of these ideas will help the readers later when they will learn about stock pricing.

The reader also learned a lot of important details about how stocks are traded. It is hoped that this information about stocks has helped the reader feel more comfortable with the idea of investing in stocks and other financial assets as well.

As was said at the beginning of the chapter, one really does not expect the reader to want to start investing career here, but it is hoped that at this point, the reader is not really out the possibility that one might find a great company that one wants to own a piece of. In future chapters, there will be given you a lot of information about how to find a great company or two.

Chapter 8 "The International debt and bond market", is about the basic notion of international credit and international strategies of trading in bonds (The textbook, pp. 261-272). The previous chapter introduced stocks by pointing how stocks are risky but fascinating. This chapter is turning to bonds.

Bonds do not have quite the same reputation as stocks. In fact, they might seem boring. It is true that bonds are not necessarily the most lucrative investments out there, but they are extremely important. And if one gets to know them a bit better, one will see that the variety and dependability of bonds can make them a very useful investment to have in the portfolio.

Bonds also play a starring role in economic policy. Bonds enable governments to borrow. 
And there are also the tools that central banks, like the Federal Reserve, use when they want to expand or shrink the money supply.

The bond market has become so large that governments have to worry about how it will react to their decisions. In fact, an advisor to President Bill Clinton remarked early in the Clinton presidency that he would like to be reincarnated as the bond market because it was the only person who could tell the President what to do.

In this chapter, the reader will learn the key features of bonds that make their returns more predictable and dependable than the returns on stocks.

This chapter is going to focus on how to pursue a buy-and-hold bond investment strategy. But the chapter will come back to active bond investing in future chapters. Although the returns on bonds might seem boring, it is clear to see that bonds themselves are really very interesting. And besides, when it comes to investment returns, a little bit boring is not such a bad thing.

The chapter focused on being a buy-and-hold bond investor. If the reader is going to follow this strategy, one will face increased default risk, inflation risk and liquidity risk. One can shrink the default risk by holding U.S. Treasuries or other government bonds, and one can mitigate the effects of inflation and liquidity risk as well by the laddering of the bonds.

If the reader follows these steps, then the biggest risk that one will have to live with is probably reinvestment risk. That means that one will always be looking for good opportunities to invest the coupon payments that one will receive. Find a good place to invest all that cash coming in - not a bad problem to have. Sometimes boring looks pretty good.

Chapter 9 "The International insurance market", is devoted to international instruments applied to insure financial assets and international insurance as a phenomenon provided and produced through diversification (The textbook, pp. 273-284). The reader has already learned about most of the essential investment opportunities and issues that one should be aware of. But there are still a few important issues and products that one needs to cover. And most importantly, one needs to think about a big picture or rather a personal big picture.

In the past few chapters, the reader has been learning about financial instruments, including when to sell the investments. This chapter is going to stick with this theme of financial instruments and get into some of the practical issues that one will need to deal with as one will have to insure the instruments that one holds, i.e. one should learn how to turn the financial plan into financial reality.

In this chapter, the reader has learned about allocating investments across all the tax-advantaged savings and insurance plans to find the right place to hold all the great investments the reader has been learning about in this course. And the reader learned about how important it is to get all the investment information organised into one place so that one can do an annual portfolio tune-up. And finally, retackle the big question of how to invest after one reaches retirement.

The chapter has demystified annuities. The reader has learned the simple do-it-yourselfalternative that one can use to manage their own retirement income or do comparison shopping for annuities.

The reader has come a very long way in this course. One may remember that one of the first chapters was about how to stop worrying and start investing. It is hoped that by now, the reader has stopped worrying and is excited to look for the right kinds of investment opportunities.

In this course, the reader learned about a full range of products that all investors should at least consider. It is hoped that the course has changed the reader's mind about a few investments that were thought too dangerous or too boring to consider before. And the textbook also showed a couple of attractive investments that it is hoped one was not aware of before.

More importantly, it is hoped the textbook has convinced the readers that they can chart their own path to investing success. No matter what they believe about market efficiency, no matter how risk-averse they are and how much or how little time they have to devote to investing, there are many good investment options to suit their particular needs. There is no need to follow the crowd. Do what is best for personal use. 
It is essential that the readers put some time on their side by investing sooner or later and making a long-term commitment to regular investing. It is hoped that this course has made the readers eager to get their current investments organised and to make plans for their future investments. In other words, it is hoped that the reader really feels prepared now to find good investment opportunities and take advantage of them. And it is also hoped the readers feel confident that they can use what they have learned in this course to reach their financial goals.

Chapter 10 "The International Movement of Capital", gives a basic idea about the free international flow of capital as based on the efficient markets hypothesis and the factors affecting international investments and international investment opportunities (The textbook, pp. 285-296). In the first chapter, the reader learned about several threats to the investments, including the wild ups and downs of the market. But one should know where some people see the threat when others see opportunity. Some people see dollar signs in those market swings, especially the upswings. And they are convinced that they should be able to make a fortune from them. Maybe not a fortune, do not be too greedy. All they really need to do is beat the market.

Beating the market is what every investor dreams about. That is what it seems like, judging by all the books, magazines, T.V. shows, websites, blogs, podcasts, live seminars and of course, spam e-mails devoted to the subject.

For example, one can do a quick search through the book section of Amazon.com and find over one hundred books that have the phrase beat the market in their title. And that does not even count the variations on that idea like Peter Lynch's bestseller called Beating the Street.

If all these different authors claim that one can beat the market, can they all be right? If they are, then there must be hundreds of different ways to beat the market. That makes beating the market sound pretty easy. But if it is so easy, then why do people need all these books on investing in telling them how to do it? These are the sort of questions the chapter is going to discuss.
In fact, the chapter is going to take an indepth look at the two really big questions that sum up all these smaller ones that have been just raised. The first of these questions is simply: Can anyone beat the market? The second then, of course, is: If someone can beat the market, how does one do it?

So, in this chapter, the reader has learned about a big decision one has to make as an investor. Do the reader think markets are highly efficient and cannot be beaten? Or does the reader think there is room for investors to beat the market by exploiting inefficiencies or correcting irrational behaviour?

If someone thinks markets are highly efficient, then their investing path is very clear. Do not try to beat the market. Join it. And if someone thinks the market can still be beaten, then they have another decision to make. Are traders willing to put in the time and effort that it takes to find those market inefficiencies? One may find out that the answer is yes. After all there is a great sense of satisfaction in being proven right and making money in the process. But it is also okay if the answer is no. The main point to remember is that traders can reach their investment goals no matter what their opinion is about market efficiency.

Chapter 11 "Russia as part of the world financial system", is specifically committed to the global economic and financial environment for contemporary Russia, the Russian ruble in the international and regional dynamics as well as the prospects of creating an international financial centre in Russia (The textbook, pp. 297-328).

The sad thing, of course, about this chapter is that it is the last one. And the book's author hopes that everybody who has been reading it has really enjoyed this very much, and it has been a terrific experience, a learning experience, academically and intellectually as well as just an experience to be amidst of this event which is as well as being in class. And so, the author hopes that the reader is looking forward to the final discussion of the aftermath of the crisis.

In this chapter, the purpose would be to understand the specifics of the Russian economy; to study the barriers which may be put in place preventing Russia from becoming a great economy; to analyse the industrial base of Russia, 
its international companies being a driving force of the Russian economy abroad; and the chapter will also strive to answer the question whether Russia indeed becomes an economic superpower by the mid-21st century like Goldman Sachs predicted back in 2003.

The major conclusions of this paragraph come out of the hypothesis that direct settlements between Brazil, Russia, India and South Africa, on the one hand, and China on the other, will lead to the creation of a new offshore centre of the yuan in Moscow by means of circulating currency vehicles traded at the Moscow Exchange. The author hereby proves based on calculating the values of Brazilian, Russian, Indian and South African exports to China and imports from China that if more favourable conditions to buy and sell the yuan at the Moscow Exchange are provided in contrast to the terms offered by the central banks, the authorised commercial banks and the Chinese Foreign Exchange Trading System (CFETS) as well as in comparison with the terms of trading in yuan by means of swap agreements between the BRICS central banks, then the non-Chinese BRICS exporters and importers will be more active in purchasing the yuan-denominated currency vehicles at the Moscow Exchange to transact with Chinese counterparts, so that not only the yuan will gradually become a more internationalised currency but also the rouble, and Moscow will become a new yuan's offshore centre and later an international financial centre.

The textbook is going to stop lecturing at this point and get out of the reader's way, so one can get out there and do just that: good luck and a happy financial and investing career.

\section{The Methodology of the Textbook} The General Strategic Purpose (GSP) of teaching world finance at the Financial University in Moscow (after that, the Financial University) is to accumulate professional skills and language fluency in the field of world finance. Professional skills in world finance can only be learned through a step-bystep approach, with specific tasks and functions at each stage being both dictated and dominated by the GSP.

In order to realise the GSP, world finance teachers, who will eventually end up using this textbook, should keep in mind the following OBLIGATIONS:

- A teacher should understand first of all the level of students' financial fluency in terms of the general economic and financial categories, for they come from various backgrounds with quite different skills and knowledge;

- Therefore, a teacher should implement a variety of entry, intermediary and final tests on a monthly, half-yearly and annual basis to find a way forward in teaching world finance;

- A teacher should use English in class and elsewhere communicating with students as much as possible;

- A teacher should divide the students into subgroups if possible and develop and think of special means to help weaker students improve their fluency in finance;

- A teacher should use as many teaching techniques as possible applying visual materials;

- Teachers should exchange teaching techniques, strategies and experience with each other;

- A teacher should make use of a diversity of discussion topics to help students communicate and express their ideas in a variety of financial fields keeping in mind the special field of their interests being international economics, business and finance;

- A teacher should preferably use the textbooks and teaching materials prescribed by the curriculum;

- A teacher should make sure that by the end of the course, the students are able to express themselves correctly in international finance.

Achieving these objectives IS NOT POSSIBLE without systematic and regular class attendance on the part of the students. Therefore, the teachers should control the students' class attendance and warn the administration of their systematic absence.

Teaching world finance is a highly interactive process that involves attention and participation on part of both the teacher and students. This process is organised through various class and extracurricular activities, such as:

1) reading economic and financial texts and articles; 
2) translation from Russian into English to be able to conduct individual studies in international finance;

3) listening activities in class and home;

4) writing skills: essays in international finance and business correspondence;

5) speaking activities in class under the teacher's supervision.

Teaching world finance at the University of Finance should pursue the following AIMS:

1) provide the basis for knowledge of facts in international finance;

2) encourage the development in students of:

a) a facility for self-expression, not only in writing but also in using additional aids such as statistics and diagrams where appropriate;

b) the habit of using works of reference as sources of data specific to economics;

c) the habit of reading critically to gain information about the changing economy in which people live;

d) an appreciation of the methods of study used by economists and of the most effective ways in which economic and financial data may be analysed, correlated, discussed and presented.

\section{Classroom activities which could be used to develop the AIMS of teaching and studying world finance}

A teacher is free to use any classroom activity he/she could think of to achieve the stated Curriculum AIMS. Here there are general classroom activities they could use in their everyday practice.

One of the most important things in providing the basics in world finance is the ability of a teacher to ask relevant questions. A correctly asked question is usually half an answer. For example, a good way to start teaching world finance is asking students how they understand the difference between the two major notions in the subject, i.e. 'What is financial economics?' and 'What is a financial economy?' because these two concepts are translated equally into Russian, though eventually, they mean different things. When the students understand the distinction, they will be immediately able to say what they are going to study and why it is of crucial importance to them, for financial economics is a science of how to make things work better in a financial economy. After that, the students will know that their function in their home country is to make the lives of people better and happier as future economists. Then the purpose of studying world finance will be clearer to them. And the purpose is to learn ways, means and techniques of providing wealth to the majority of the population in their home country.

Statistical data is the basis of world finance. Economic problems can only be solved when the students see what is wrong with the data. They should be able to make clear what these figures mean to them personally because economists could be clients and customers and scientists or producers at the same time.

That is why the repeated use of statistics is so important in studying world finance. One of the methods to nurture the students to look through various statistical data is to make them complete simple tasks. For example, a probable home task here could be asking the students, 'What are the biggest corporations in Russia?' The teacher tells them, 'This could be found in the rating of Fortune Global 500 on the Fortune's official website'. The teacher then may encourage the students to search for that data by telling them that they can work for those companies in the future and get a competitive salary and that in order to apply for a job in such a company, they should at least know those firms' names.

There are many notions in finance. Some of them, such as inflation, oil prices, economic growth, exchange rates, etc., are of everyday importance, for if they change, our lives will also change. The greater they vary, the more dramatic the effects on people's lives they will produce. To make sure the students are aware of this current information, the teacher should ask them each lesson, for example, 'How much does crude oil cost today', or, 'What is the exchange rate of one Russian rouble to the U.S. dollar?'

If the students are encouraged to collect such data every day, the teacher may ask them to organise the figures in tables. Then the teacher explains to them that there is a method of predicting how, for example, the exchange rate of the rouble to the dollar fluctuates in a given period. The teacher, in his/her turn, 
writes a mathematical formula on the white/ blackboard and tells the students this is a simplified way of how the FOREX market operates and that they, by making use of the formula, may participate in it, thus persuading them that there is a practical use of the economic methods they study.

The recommended classroom activities would help to develop the curriculum AIMS because:

1) The first suggested classroom activity - asking relevant questions - establishes the right direction in the course of studies for the students. As time passes, they will learn how to see through a difficult text to achieve a particular aim because they will know the roadmap;

2) Secondly, as organising statistical data is the key to understanding economic problems, the ability to construct diagrams or economic tables is one of the ways to meet the course's goals, that is encompassing fundamental knowledge in world finance for the students;

3) Thirdly, when the students are used to collect and memorise current economic and financial data as well as make practical sense out of the data, they will be able to formulate an economic problem in one sentence at least. When formulated, economic problems can be better understood and solved by subdividing them into a group of tasks to be accomplished. Fulfilling these subtasks one by one, the students will be able to develop an ability to solve aggregate economic problems;

4) Fourth, economists are usually sceptic or pragmatic sorts of people who question each event and think something that is happening is not true. Therefore, developing the aims of the course means teaching the students to scrutinise each and every aspect of everyday life. A major question for an economist is, 'Why is it so and not otherwise?' Economists should also be the sceptic in times of prosperity when nobody thinks that there will be a crash on the stock market tomorrow. They should be able to predict that;

5) Finally, in order to predict something, the students should be aware of the methods used to foresee future economic events. In this way, solving mathematical equations is a way to achieve the course's goals.
Can more than one Curriculum AIM be met with a single classroom activity?

It would be an ideal style of teaching if at least two aims of the course could be achieved just by one of the above classroom activities. A suggested answer here could be that asking provocative questions can provide an opportunity for the students to express themselves clearly and learn the basics of world finance at the same time.

Are any of your current classroom activities meeting these AIMS?

This is a really important question to ask yourself when teaching world finance. Basically, even if one of the course's aims cannot be achieved by the above classroom activities, there is no use in teaching world finance under the circumstances such as these, because this particular course of studies is an integrated learning process, and if its major aims cannot be achieved, the students will not be able to make any sense of it and will never become true economists.

Can any of your existing lesson plans be adapted to meet these aims?

It is a different situation when a teacher improves and develops his/her classroom activities on a day-to-day basis. His/her plans should always be adapted in order to find an optimal way of achieving the course's GSP and AIMS. In this particular situation, any teaching method of trying to find alternative classroom activities that could help achieve two or more of the given AIMS simultaneously would actually be an ideal means of a lesson plan's adjustment.

The textbook is structured in a way to give the general idea of the contemporary global financial system. It consists of eleven chapters, each of which has a specific area of world finance to describe. It starts with theoretical issues on financial assets used in the world of international finance. It then outlays the foundation of international financial relations. It contains chapters on the specific roles of central banks and many other important financial institutions, including the International Monetary Fund and the World Bank.

The textbook has some practical issues to discuss, such as crisis management during the most dramatic periods of world economic history, such as the Great Depression, the Asian 
Slow but steady progress

Using a combination of class activities, i.e. discussions, role plays, business games, making presentations, projects, brainstorming, etc.

Assigning projects

Interaction
A strategy like this sets achievable goals, so that with a minor goal reached, students will be able to proceed in the course and fulfil future goals

This strategy develops a complex approach to the subject and trains specific skills

Such activity directs students to work not only in class but also at home and teaches them to be self-sufficient

Interaction between a teacher and a student through various means of communication, from simple e-mail contact to face-to-face total interaction, develops skills such as being sociable, communicative, without being afraid to get into the conversation. Using various interactions with no direct face-to-face contact, students can get in touch with their teacher any time and receive a consultation, should any problem occur.
Financial Crisis and the world financial crisis of 2008-2010.

The textbook ends up with detailing the role of Russia and the Russian rouble in world finance.

\section{Conclusion}

The world finance course graduates from the University of Finance are expected to:

1) DEMONSTRATE KNOWLEDGE AND UNDERSTANDING of the specific international financial content;

2) INTERPRET international economic and financial data presented in verbal, numerical or graphical form;

3) EXPLAIN AND ANALYSE international economic and financial issues and arguments, using relevant economic concepts, theories and information;

4) EVALUATE international economic and financial information, arguments, proposals and policies taking into consideration relevant financial information and theory, and distinguishing facts from hypothetical statements and value judgements;

5) ORGANISE, PRESENT AND COMMUNICATE international economic and financial ideas and informed judgements in a clear, logical and appropriate form.

Teaching methods/activities that might be used to develop each of these five assessment objectives
In order to develop the first assessment objective, it is very important to make sure on a regular basis that students understand the economic and financial categories studied previously. Usually, it is done through regular asking the students to define a particular notion of economics and finance in English. If answered wrongly, the teacher should put additional questions to manoeuvre him/her in the right direction. Sometimes it is not a matter of a student forgetting the correct answer. Still, when being excited a little bit by the difficulty of a question, the student mistakes one economic or financial category for another.

This technique of helping or manoeuvring questions can be a powerful tool in developing students' ability to demonstrate and understanding things.

It is a misconception that the students of financial science cannot interpret verbal, numerical or graphical information if they are starters in learning the subject. Finance is a practical, everyday science and not just a combination of some static notions and theories. The students of finance are pupils as well as consumers, clients or customers who are to take simple financial and economic decisions every day in a bookstore, marketplace, etc. They can always say something or express an opinion of theirs on particular verbal information if it is correctly formulated. 
Slow but steady progress a) It allows students with no knowledge in world finance to catch up with more advanced ones;

b) A strategy of achieving objectives directly will create gaps in students' minds, and their competence will be discretionary

It produces a complete picture of a student's competence in this particular course, for it does not only teach him/her to read and write but also listen to and communicate with each other

It develops in students the skills of working individually which is very important, for it is Assigning projects

Interaction
Students can always turn to their teacher for help a) Sometimes, it creates a feeling a higher goal is not achievable at all if it needs many stages to approach it;

b) It consumes more teaching time than a strategy to reach direct goals

It requires a total commitment of a teacher to the course, for he/ she are to use each minute wisely, are to develop detailed plans for each lesson and eventually such a strategy takes lots of teaching time

It requires both responsibility and commitment of students to the course, which is very difficult for a teacher to ensure

It requires much spare time free of work and a teacher's personal time
Some students find it difficult to interpret numerical information. But statistics data can be organised in the form of a graph. And graphical information can always be easily interpreted because, if figures are organised in curves, the resulting graphs show increasing or decreasing trends, e.g. in supply or demand. So, when the students see the demand curve decreasing, they will immediately say that means the consumers stopped purchasing a particular product and vice versa.

Suppose the students know the basic economic laws, such as the laws of supply and demand. In that case, they will be able to critically explain and analyse particular economic issues and arguments they read in books on finance, business magazines or newspapers or hear some politician or economist say something on the radio or T.V. and make their own corrections afterwards.
The next stage can be accomplished only when the students are no longer starters in studying finance. That presupposes they have already mastered many economic laws and theories. A powerful tool here can be to make the students hypothesise. Intuition can help here at the initial stages. A teacher's role in this specific example is to promote and motivate the students to express any idea that occurs to their mind. And of the ideas generated by a team of students, those can be chosen that best correspond to the economic theories and laws they know.

To develop the final assessment objective, it is very important to stimulate the students in making their own presentations on the topic that is being taught in class at the moment. While preparing such presentations, it is crucial that the students use modern means of 
demonstrating their economic theses, i.e. computers, slideshows or even video conferencing. The students should be given each opportunity to communicate with both their teacher and colleagues.

Suppose a world finance teacher realises the students are able to interpret the material that has been learned. In that case, he/ she may go over to explaining to them the categories of the proceeding units. Otherwise, he/she could try to clarify why the students answered wrongly to certain questions. At this point, it is really crucial to look into the core of an incorrect answer because if the teacher finds it, he/she will definitely discover the means and techniques of helping their students generate proper knowledge of the concepts studied.

\section{Different teaching strategies that a world finance teacher may use or plan to use as well as particular skills that are being developed by using them}

The most important thing in achieving the aims and objectives of the course is progression. It is impossible to accomplish any of the required tasks and assignments without a step-by-step approach. It is why world finance teachers may choose slow but steady progress as core teaching strategies. It is followed by a strategy of combining different classroom activities, which will help students develop the skills required by the course. An ineffective teaching method here would be doing the same thing all the time at each lesson, e.g. reading and understanding a given text as it is usually done in the local language courses of study. Such a strategy develops nothing but reading skills, whereas the approach prescribed here is to unite a variety of skills and train them simultaneously. This way, students will be more interested in the course, and they will not find the lessons boring.

Using the strategy of assigning projects, world finance teachers should try to develop creativity in the students and get feedback from them. Finally, taking the above strategies together, world finance teachers need constant communication with the students, for if there is no interaction, that will mean the teacher is not interested in his/her students achieving the course's aims and objectives, and the students will have to look for alternative studies.

Applying these strategies will always make world finance lessons more interesting. It will create in the students a desire to express themselves and communicate with their classmates on international financial issues. It will also develop in them many of the skills mentioned above, i.e., they will be trained to be good listeners. They will respect each other as a team of professionals and express themselves correctly, following their teacher's advice and comments. What may prevent world finance teachers from accomplishing these strategies is a constant need to find sufficient time, which is the commonest problem with teaching. A teacher may be required to use teaching time more wisely, to make the strategies work better, learn and find ways to manage it, and constantly contact people in the field and exchange experience with them.

Other teaching strategies that can be used in teaching practice may include connecting some parts of the learning process to a particular student's specialisation field, that is, the job he/she does on a regular basis.

\section{References}

Boddin, D., Stähler, F. (2018). The Organization of international trade. CESifo Working Paper, 7378, 6-10.

Beetsma, R., Giuliodori, M., De Jong, F., Widijanto, D. (2016). Price Effects of Sovereign Debt Auctions In the Euro-Zone: The Role Of the Crisis. Journal of Financial Intermediation, 25, 30-53.

Cohen, B.J. (2012). The Benefits and Costs of an International Currency: Getting the Calculus Right. Open Economies Review, 23(1), 16-17.

De Haas, R., Horen, N. van. (2011). Running for the Exit: International Banks and Crisis Transmission. EBRD Working Paper, 124, 2.

Dorrucci, E., McKay, J. (2011). The international monetary system after the financial crisis. European Central Bank Occasional Paper Series, 123, 10. 
Gourinchas, P.-O., Obstfeld, M. (2012). Stories of the Twentieth Century for the Twenty-First. American Economic Journal: Macroeconomics, 4(1), 226-265.

Johnson, J. (2013). The Russian Federation: International Monetary Reform and Currency Internationalization. The BRICS and Asia, Currency Internationalisation and International Monetary Reform, 3, 6-15.

Kadayan, H. (2014). Indian rupee's role as an international currency. Abhinav - National Monthly Refereed Journal in Commerce \& Management, 2(3), 35-43.

Kasekende, L., Brixova, Z., Ndikumana, L. (2010). Africa: Africa's Counter-Cyclical Policy Responses to the Crisis. Journal of Globalization and Development, $1,1$.

Khan, K., Zhao, H. W., Zhang, H., Yang, H. L., Haroon, M., \& Jahanger, A. (2020). The Impact of COVID-19 Pandemic on Stock Markets: An Empirical Analysis of World Major Stock Indices. Journal of Asian Finance Economics and Business. 7(7): 463-474. doi: 10.13106/jafeb.2020.vol7.no7.463

Lane, P.R., Milesi-Ferretti, G.M. (2011). The Cross-Country Incidence of the Global Crisis. IMF Economic Review, 59(1), 77-110.

Milesi-Ferretti, G.M., Tille, C. (2011). The Great Retrenchment: International Capital Flows During the Global Financial Crisis. Economic Policy, 26(66), 285-342.

Obstfeld, M. (2011). The International Monetary System: Living With Asymmetry. NBER Working Papers, 12596, 14.

Ostry, J. (2012). Managing Capital Flows: What Tools to Use? Asian Development Review, 1, 82-88.

Patil, S.R., Kulkarni, R.R. (2011). Internationalisation of Indian rupee - an empirical study. International Journal of Research in Commerce, Economics and Management, 1, 45-49.

Reinhart, C.M., Rogoff, K.S. (2011). From Financial Crash to Debt Crisis. American Economic Review, 101(5), 1676-1706.

Rousseau, P.L., Wachtel, P. (2011). What is happening to the impact of financial deepening on economic growth? Economic Inquiry, 49(1), 276-288.

Salisu, A. A., \& Akanni, L. O. (2020). Constructing a Global Fear Index for the COVID-19 Pandemic. Emerging Markets Finance and Trade. 56(10): 2310-2331. doi: 10.1080/1540496X.2020.1785424

Tripathi, V., \& Kaur, A. (2020). Socially responsible investing: performance evaluation of BRICS nations. Journal of Advances in Management Research. 17(4): 525-547. doi: 10.1108/JAMR-02-2020-0020

Vayanos, D., Woolley, P. (2013). An Institutional Theory of Momentum and Reversal. Review of Financial Studies, 26(5), 1087-1145.

Yu, Y. (2014). How Far Can Renminbi Internationalization Go? Asian Development Bank Institute's Working Paper, 461, 9-15.

\section{ABOUT THE AUTHOR}

Mikhail V. Zharikov in 2010 defended his PhD thesis on the topic: "Marketing strategies of BRIC corporations in the foreign market". In 2015, he was awarded the Honorary Doctor of Science (Honoris Causa) of the Russian Academy of Natural Sciences. In 2017, he defended his doctoral dissertation on the topic: "Internationalisation of the currencies of the BRICS countries" at the Lomonosov Moscow State University. In 2011-2018, Associate Professor of the Department of International Economic Relations of the Russian Customs Academy. Since 2018 Professor of the Department of World Economy and World Finance at the Financial University under the Government of the Russian Federation. Since 2018, Chief Researcher of the Department of Economic Research at the Institute of Europe of the Russian Academy of Sciences. In 2011, he received a Certificate from the University of Cambridge for teaching Economics in English Teacher of Economics.

He works at World Finance Department, Professor; Financial University, Moscow, Russia. He teaches the disciplines "World Economy and international economic relations", "International monetary and credit relations", "International Financial Market" and" International Conventions and Agreements on trade". Teaches the disciplines "Marketing”, "Branding”, “World Economy”, “International Financial Market”, "International Banking", "International practice of project finance" in English.

michaelzharikoff@gmail.com

http://orcid.org/0000-0002-2162-5056 


\title{
Мировые финансы: Презентация и обзор учебника
}

\author{
Михаил Жариков
}

\begin{abstract}
АННОТАЦИЯ
Учебник предназначен для студентов, изучающих современные финансы, и всех читателей, интересующихся данной проблематикой. Предложен оригинальный способ освещения широкого круга вопросов. Написан живым, интерактивным языком. Вопросы поставлены таким образом, чтобы заставить студента думать и самостоятельно искать на них ответы. Структура учебника, построенная по классическому образцу зарубежных пособий и учебников, состоит из одиннадцати глав, охватывающих весь спектр современных международных финансовых отношений. Каждая глава завершается вопросником для самоконтроля. Учебник насыщен фактографическим материалом и содержательными экскурсами в историю современных финансов, что позволяет читателю лучше понять теоретические выкладки. Издание учебника весьма актуально, особенно для студентов и преподавателей дисциплин по международным финансам на английском языке. Дополняет учебник словарь финансовых понятий и терминов.
\end{abstract}

Ключевые слова: международные финансы; дисконтирование; финансовая глобализация

\section{ОБ АВТОРЕ}

Михаил Жариков - доктор экономических наук, доцент, профессор. В 2010 г. защитил кандидатскую диссертацию на тему: «Маркетинговые стратегии корпораций стран БРИК на внешнем рынке». В 2015 г. присвоено звание почетного доктора наук (Doctor of Science, Honoris Causa) Российской академии естествознания. В 2017 г. защитил докторскую диссертацию на тему: «Интернационализация валют стран БРИКС» в Московском государственном университете им. М.В. Ломоносова. С 2018 г. профессор Департамента мировой экономики и мировых финансов Финансового университета при Правительстве РФ. 